Journal of Educational Method and Technology Vol. 2 No. 1, April 2019

P-ISSN 2622-8459 E-ISSN 2622-8467

http://ejournal.unima.ac.id/index.php/jemtec

\title{
Teaching Wh-Question To Young Learners Through Picture For Sekami Of Paroki Roh Kudus Tomohon
}

\author{
J Tuilan ${ }^{1}$ \\ ${ }^{1}$ Universitas Negeri Manado, Indonesia \\ corresponding author: ${ }^{1}$ jeanetuilan@unima.ac.id
}

\begin{abstract}
This study intends to find out the effectiveness of using picture as teaching media in teaching WH-Question. The Subject consisted of 10 young aged students attending SEKAMI during the period November 2018 - February 2019. The data were collected through objective test pre-experimental design of one group pre-test post-test. The data were analyzed based on descriptive statistics, in which the mean of pre-test was compared to the mean of post-test. The finding shows that students improved their achievement after being treated with picture. The mean of post-test is higher than the mean of pre-test $\left(X_{2}\right.$ is higher than that of $\left.X_{1}=82.5>61.5\right)$. This indicates that the use of picture as a teaching media was interesting and made the students easy to understand the situation that had been explained to them.
\end{abstract}

Keywords: WH-Question, Young learners, teaching through picture.

\section{Introduction}

Facing the needs of people in this era that prepare the human resources for competitive skill and be ready for science and technology sector in international competition, making English become a very important language. That is the reason why we should study and understand English. At it is understood from lots of studies about learning language, it is the best learned language at an early age which means from birth to the school time. English as a language have the same reason. However, the question is how to teach English to young learners. Language teaching, particularly English is thought to be appropriate and effective when it begins at earlier age of learners. This is true as stated by Philips (1993:7), "the younger the children are the more holistic they will be. Younger learners respond to language according to what they do or what they can do with it. Rather than treating it is an intellectual game or abstract system. It can be concluded that it easier for children to learn a foreign language, because they do not care about the abstract system but just respond it according to what they can do with it instead". Based on that the researcher is interested in conducting research on teaching wh-questions to young learner through picture. Young learners of SEKAMI of Paroki Roh Kudus Tomohon are chosen as the object. SEKAMI stands for Serikat Kepausan Anak-anak Misioner. They are young children at elementary level. 


\section{Methods}

This study was use the One-Group Pretest-Posttest design. Thus, it is also a pre-experimental design. About this type of design, Sugiono (2008:295) points out, "Bila ingin mengetahui pengaruh perlakuan/treatment tertentu terhadap yang lain. Untuk kepentingan ini metode eksperimen paling cocok digunakan." About this kind of design, Hatch and Farhady (1982:20) state: "One group Pre-test Post-test Design is similar to one shot case study; the difference is that a pre-test is given berfore the instruction (or treatment) begins".

The subject of this research were taken from SEKAMI Paroki Roh Kudus Tomohon, in which 10 students of elementary level became the subjects.

Test was used as the instrument of this research, in this case objective test. It was given before the treatment as pretest, and after the treatment as post test. Both consisted of 20 items, which means that for each correct answer on its item, the point 5 (five) was given. The treatment was teaching WH-Questions through picture to the subject. To analyze the data, descriptive statistical analysis was used. In this case, the mean of tests (pretest and posttest) were compared.

The following procedures were followed in conducting this research:

a. Choosing the sample to be the subject of the study.

b. Preparing lesson plan for teaching and learning process.

c. Preparing the treatment material as practice to be done by subject.

d. Conducting pre-test to have a general picture about achievement of $\mathrm{WH}-$ Questions.

e. Giving treatment based on the use of cloze procedure.

f. Giving post-test to check whether there is an improvement of achievement of WH-question.

g. Computing the results of the post-test through means.

h. Comparing the result of the pre-test to have the final conclusion of the research.

\section{Findings and discussion}

It has mentioned earlier that the subjects of this research consisted of 10 SEKAMI young learners. The design used was pre-experimental. The data are presented in matrix and table of frequency distribution, and bar chart. The data of this research were collected through objective test given as pre-test $\left(\mathrm{T}_{1}\right)$ and post-test $\left(\mathrm{T}_{2}\right)$. The pre-test was given to the group before the treatment was done, while the post-test was given to the group after the treatment was done. The pre-test symbolized as $X_{1}$ while the post-test was symbolized as $X_{2}$, and the treatment was symbolized by $\mathrm{X}$. This treatment was actually the application of picture in teaching learning process. In order to find the significance difference between the two tests, the mean $(\mathrm{X})$ formula was applied. Then, the scores of pre-test and post-test can be determined. 
Table 1. The Students' scores in $\mathrm{X}_{1}$ and $\mathrm{X}_{2}$

\begin{tabular}{|c|c|c|}
\hline $\mathrm{N}$ & $\mathrm{X}_{1}$ & $\mathrm{X}_{2}$ \\
\hline 1 & 60 & 80 \\
\hline 2 & 50 & 80 \\
\hline 3 & 75 & 90 \\
\hline 4 & 70 & 90 \\
\hline 5 & 65 & 80 \\
\hline 6 & 50 & 75 \\
\hline 7 & 60 & 80 \\
\hline 8 & 70 & 90 \\
\hline 9 & 65 & 80 \\
\hline 10 & 50 & 80 \\
\hline
\end{tabular}

Based on the data in Table 1, frequency distributions of pre-test and post-test scores were computed. The computation began with the computation frequency distribution of pre-test scores. Result of the computation is depicted in Table 2.

Table 2. Frequency and Percentage Distributions of $\mathrm{X}_{1}$

\begin{tabular}{|c|c|c|c|c|c|}
\hline \multicolumn{7}{|c|}{ Pre-Test } \\
\hline Score & Tally & Frequency & Freq \% & Cum- Freq- & Cum- \% \\
\hline 75 & I & 1 & $10 \%$ & 10 & $100 \%$ \\
\hline 70 & II & 2 & $20 \%$ & 9 & $90 \%$ \\
\hline 65 & II & 2 & $20 \%$ & 7 & $70 \%$ \\
\hline 60 & II & 2 & $20 \%$ & 5 & $50 \%$ \\
\hline 50 & III & 3 & $30 \%$ & 3 & $30 \%$ \\
\hline
\end{tabular}

Having computed the frequency distribution of pre-test, the frequency of post-test was computed. The result of computation is depicted in Table 3.

Table 3. Frequency and Percentage Distributions of $\mathrm{X}_{2}$

\begin{tabular}{|c|c|c|c|c|c|}
\hline \multicolumn{6}{|c|}{ Post-Test } \\
\hline Score & Tally & Frequency & Freq \% & Cum- Freq- & Cum- \% \\
\hline 90 & III & 3 & $30 \%$ & 10 & $100 \%$ \\
\hline 80 & IIII I & 6 & $60 \%$ & 7 & $70 \%$ \\
\hline 70 & I & 1 & $10 \%$ & 1 & $10 \%$ \\
\hline
\end{tabular}

Having computed the frequency distributions of pre-test and post-test, the data analysis was continued with the computation of mean. The mean was computed using this formula:

$$
\bar{X}=\frac{\sum X}{n}
$$

To make the computation easier, the sum of $\mathrm{X}_{1}$ and $\mathrm{X}_{2}$ be computed first. The results are presented in Table 4. 
Journal of Educational Method and Technology Vol. 2 No. 1, April 2019

P-ISSN 2622-8459 E-ISSN 2622-8467

http://ejournal.unima.ac.id/index.php/jemtec

Table 4. Result of Computation of $\sum \mathrm{X}_{1}$ and $\sum \mathrm{X}_{2}$

\begin{tabular}{|c|c|c|}
\hline $\mathrm{N}$ & $\mathrm{X}_{1}$ & $\mathrm{X}_{2}$ \\
\hline 1 & 60 & 80 \\
\hline 2 & 50 & 80 \\
\hline 3 & 75 & 90 \\
\hline 4 & 70 & 90 \\
\hline 5 & 65 & 80 \\
\hline 6 & 50 & 75 \\
\hline 7 & 60 & 80 \\
\hline 8 & 70 & 90 \\
\hline 9 & 65 & 80 \\
\hline 10 & 50 & 80 \\
\hline & $\sum \mathrm{X}_{1}=615$ & $\sum \mathrm{X}_{2}=825$ \\
\hline $\mathbf{n}$ & 61.5 & 82.5 \\
\hline
\end{tabular}

Standard deviation symbolized as S, was computed using Raw Score method or formula:

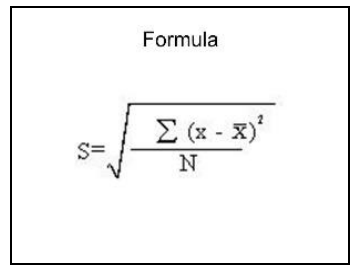

The result will be shown in Table 5 and Table 6 .

Table 5. Standard Deviation of $\mathrm{X}_{1}$

\begin{tabular}{|c|c|c|}
\hline $\mathrm{N}$ & $\mathrm{X}_{1}$ & $\mathrm{X}_{1}{ }^{2}$ \\
\hline 1 & 60 & 3600 \\
\hline 2 & 50 & 2500 \\
\hline 3 & 75 & 5625 \\
\hline 4 & 70 & 4900 \\
\hline 5 & 65 & 4225 \\
\hline 6 & 50 & 2500 \\
\hline 7 & 60 & 3600 \\
\hline 8 & 70 & 4900 \\
\hline 9 & 65 & 4225 \\
\hline 10 & 50 & 2500 \\
\hline $\mathrm{S}_{1}$ & $\sum \mathrm{X}_{1}=615$ & $\sum \mathrm{X}_{1}{ }^{2}=38575$ \\
\hline
\end{tabular}


Table 6. Standard Deviation of $\mathrm{X}_{2}$

\begin{tabular}{|c|c|c|}
\hline $\mathrm{N}$ & $\mathrm{X}_{2}$ & $\mathrm{X}_{2}{ }^{2}$ \\
\hline 1 & 80 & 6400 \\
\hline 2 & 80 & 6400 \\
\hline 3 & 90 & 8100 \\
\hline 4 & 90 & 8100 \\
\hline 5 & 80 & 6400 \\
\hline 6 & 75 & 5625 \\
\hline 7 & 80 & 6400 \\
\hline 8 & 90 & 8100 \\
\hline 9 & 80 & 6400 \\
\hline 10 & 80 & 6400 \\
\hline & $\sum \mathrm{X}_{2}=825$ & 68325 \\
\hline$S^{2}$ & $\sqrt{68325 / 10-82.5^{2}}$ & 5.1 \\
\hline
\end{tabular}

The comparison of the two Mean and Standard Deviation is depicted in Table 7.

Table 7. Mean and Standard Deviation Comparison

\begin{tabular}{|c|c|c|}
\hline & Pre-Test & Post-Test \\
\hline Mean & 61.5 & 82.5 \\
\hline Standard Deviation & 8.7 & 5.1 \\
\hline
\end{tabular}

Based on the findings as pointed out above, it can be seen that using picture is effective in teaching English WH-Question. This can be understood from the different achievement of the subjects in $X_{1}$ in which they had not been treated with pictures, and in $\mathrm{X}_{2}$ in which they had been treated with pictures. The score value mean in $\mathrm{X} 1$ is 61.5 , and the score value mean in $\mathrm{X}_{2}$ is 82.5 . The mean of $\mathrm{X}_{2}$ is larger than $\mathrm{X}_{1}$, which indicates the treatment is effective.

\section{Conclusion}

The implementation of teaching WH-Question to English young learners through picture was interesting and made the students easy to understand the situation that had been explained to subject.

Based on the research, using picture in teaching WH-Question can develop students' understanding of the subject. It means that, in general the use of picture as teaching media in teaching WH-Question is effective.

\section{Suggestion}

Based on the conclusion, it is suggested:

1. English instructors or teachers of the young aged students should apply the use of picture in the learning process for better outcomes.

2. It is advised that English instructors or teachers have enough background of English education especially for young learners. 
Journal of Educational Method and Technology Vol. 2 No. 1, April 2019

P-ISSN 2622-8459 E-ISSN 2622-8467

http://ejournal.unima.ac.id/index.php/jemtec

\section{References}

Azar, B. S. \& Hagen, S. A. 2009. Understanding and Using English Grammar Fourth Edition. New York: Person Longman.

Brown, D. H. 1994. Teaching by Principles. New York: Prentice Hall. , 2007. Prinsip Pembelajaran dan Pengajaran Bahasa. Jakarta: Kedutaan Besar Amerika Serikat di Jakarta.

Fallik, F \& Brown, B. 1983. Statistics for Behavioral Sciences. Homewood: The Dorsey Press.

Halliwell, S. 1992. Teaching English in the Primary Classroom. Spain: Graficas Estella S.A.

Phillips, S. 1993. Young Learners, Resource Book of Teachers. Oxford: Oxford University Press.

Sugiono. 2008. Metode Penelitian Pendidikan. Bandung: Alfabeta Group.

Suyanto, K. 2007. English for Young Learners. Jakarta: PT. Bumi Aksara. 